\title{
Comparison of Cortisol Responses to Low Dose ACTH Stimuli and Injection Stress
}

\author{
Aysenur Ozderya $^{1 \oplus}$, Sule Temizkan $^{1 \oplus}$, Kadriye Aydin $^{1 \oplus}$
}

\begin{abstract}
:
Comparison of cortisol responses to low dose ACTH stimuli and injection stress

Objective: We performed a placebo-controlled, single-blind, pilot study to compare the efficacy and safety of low dose cosyntropin stimulation test with injection stress in the diagnosis of secondary adrenocortical insufficiency.

Material and Methods: Twenty-five patients (22 F, 3 M) with a low or normal plasma ACTH level, morning plasma cortisol level $<15 \mu \mathrm{g} / \mathrm{dL}$ and an indication of cosyntropin stimulation test for secondary adrenocortical insufficiency were included in the study. On the first day, the test was performed with direct intravenous injection with $1 \mathrm{~mL} 0.9 \%$ saline. On the second day at the same time and with the same method, the test was repeated with $1 \mu \mathrm{g} / \mathrm{mL}$ cosyntropin solution. Immediately prior to the procedure, blood samples were taken from the cannula located in the other forearm for measurement of plasma cortisol at $30^{\text {th }}$ and $60^{\text {th }}$ minutes.
\end{abstract}

Results: The median ACTH value of the patients selected for the study was $22.10 \mathrm{pg} / \mathrm{mL}(14.00$ 29.30) and the mean plasma cortisol level was $6.71 \pm 2.00 \mu \mathrm{g} / \mathrm{dL}$. The baseline plasma cortisol values measured at one minute in the placebo-controlled tests for comparison of injection stress with $1 \mu \mathrm{g}$ cosyntropin stimulation were similar, but a significant statistically significant difference was found between plasma cortisol values measured at $30^{\text {th }}$ and $60^{\text {th }}$ minutes $(p<0.001)$.

Conclusion: Injection stress, which occurs during intravenous injection, does not cause an increase in cortisol responses. However, $1 \mu \mathrm{g}$ cosyntropin stimulation test at the physiological doses produces a significant cortisol response, especially at 30 minutes.

Keywords: Adrenal insufficiency, cortisol, injection stress stimuli, low-dose cosyntropin stimulation test

\section{ÖZET:}

Enjeksiyon stresi ve düşük doz ACTH uyarısında kortizol yanıtlarının karşılaştırılması

Amaç: Sekonder adrenal yetmezlik tanısında düşük doz kosintropin stimülasyon testinin etkinlik ve güvenilirliğini enjeksiyon stresi ile karşılaştırmak için plasebo kontrollü, tek kör, pilot bir çalışma yaptık. Gereç ve Yöntemler: Çalışmaya plazma ACTH değeri düşük ya da normal, sabah plazma kortizol değeri $<15 \mu \mathrm{g} / \mathrm{dL}$ olan ve sekonder adrenal yetmezlik tanısı için kosintropin uyarı testi endikasyonu olan 25 hasta $(22 \mathrm{~K}, 3 \mathrm{E}$ ) alındı. il g gün test, $1 \mathrm{~mL} \% 0.9$ serum fizyolojik ile direkt intravenöz enjeksiyon şeklinde yapıldı. İkinci gün aynı saatte ve yöntemle test $1 \mu \mathrm{g} / \mathrm{mL}$ kosintropin solüsyonu ile tekrarlandı. İşlemden hemen önce, 30 ve 60. dakikalarda plazma kortizol ölçümü için diğer ön kolada hazır bulunan kanülden kan örnekleri alındı.

Bulgular: Çalışmaya seçilen hastaların medyan ACTH değeri 22.10 pg/mL (14.00-29.30), ortalama plazma kortizol değeri $6.71 \pm 2.00 \mu \mathrm{g} / \mathrm{dL}$ idi. $1 \mu \mathrm{g}$ kosintropin stimulasyonu ve enjeksiyon stresinin karşılaştırılması için yapılan plasebo testte 0 . dakikada ölçülen bazal plazma kortizol değerleri benzer iken, 30. ve 60. dakikada ölçülen plazma kortizol değerleri arasında belirgin şekilde istatistiksel anlamlı fark saptandı ( $p<0.001$ ).

Sonuç: Intravenöz enjeksiyon esnasında oluşan enjeksiyon stresi kortizol yanıtlarında artışa sebep olmamaktadır. Oysa fizyolojik dozdaki $1 \mu \mathrm{g}$ kosintropin stimulasyonu özellikle 30. dakikada belirgin bir kortizol yanıtı oluşturur.

Anahtar kelimeler: Adrenal yetmezlik, kortizol, enjeksiyon stres uyarısı, düşük doz kosintropin stimülasyon testi

\section{Ş.E.E.A.H. Tıp Bülteni 2017;51(4):278-82}

${ }^{1}$ Health Sciences University, Kartal Dr. Lutfi Kirdar Training and Research Hospital, Department of Endocrinology and Metabolism Diseases, Istanbul - Turkey

Address reprint requests to / Yazışma Adresi: Aysenur Ozderya,

Health Sciences University, Kartal Dr. Lutfi Kirdar Training and Research Hospital, Department of Endocrinology and Metabolism Diseases, Istanbul - Turkey

E-mail / E-posta: aysenur.ozderya@gmail.com

Phone / Telefon: +90-505-371-3969

Date of receipt / Geliş tarihi: August 15, 2017 / 15 Ağustos 2017

Date of acceptance / Kabul tarihi: Septebmer 11, 2017 / 11 Eylül 2017 


\section{INTRODUCTION}

Adrenal insufficiency (AI), may occur from the impairment of primary function of the adrenal glands, insufficiency of adrenocorticotropic hormone (ACTH) secretion from hypothalamic-pituitary diseases or sudden withdrawal of chronic steroid therapy. Al diagnosis is usually simple in the presence of clinical and laboratory findings. However, recognition of subclinical cases is more problematic and early recognition of these forms is crucial. Al is a lifethreatening condition when adequate replacement therapy is not performed. Subclinical cases usually have normal basal cortisol and ACTH levels, and many symptoms (anorexia, weight loss, fatigue, etc.) are insidious and uncertain (1).

Cortisol secretion follows a circadian pattern; the highest concentrations are observed in the morning (at around 6:00) and range from 10 to $20 \mu \mathrm{g} / \mathrm{dL}$. Low morning serum cortisol concentration $(<3 \mu \mathrm{g} / \mathrm{dL})$ strongly supports $\mathrm{Al}$ and $\mathrm{Al}$ is excluded in almost all patients when morning serum cortisol concentration is $>15 \mu \mathrm{g} / \mathrm{dL}$. However, serum cortisol levels between 3 and $15 \mu \mathrm{g} / \mathrm{dL}$ do not show neither adrenal insufficiency nor adequacy (2).

The diagnosis of $\mathrm{Al}$ is based on the demonstration of inappropriately low cortisol production, and prompt diagnosis is important to remove the risk of acute adrenal crisis in patients with suspected AI. A number of dynamic tests can be performed to evaluate the hypothalamic-pituitary-adrenal (HPA) axis. But there is still a considerable debate regarding which is the best.

The insulin tolerance test (ITT) was accepted as the "gold standard" for detecting secondary adrenal insufficiency. However, the use of this test requires careful supervision and experience. In addition, because of its side effects and contraindications, other screening tests that are simpler, safer and more reliable are needed $(3,4)$. The traditional $[250 \mu \mathrm{g}$ tetracosactide, ACTH-(1-24)] cosyntropin stimulation test (CST) which is performed with administration of $250 \mu \mathrm{g}$ ACTH intravenously is frequently criticized for being at supraphysiological doses and with its suboptimal sensitivity and may dismiss mild adrenal insufficiency cases $(5,6)$. In recent years, it has been shown that the $1 \mu \mathrm{g}$ ACTH (Low-Dose Cosyntropin Stimulation Test, LDCST) test has a high specificity and sensitivity for the assessment of central Al in patients with hypothalamic-pituitary disorders and its strong correlation with ITT (6-8). However, in many studies it is still suggested that the LDCST is more sensitive than the $250 \mu \mathrm{g}$ ACTH test, but this condition is controversial (6).

LDCST has a more physiological dose compared to CST. However, there is no study comparing this dose with physiological stress. For this reason, in this study, we aimed to compare only the serum cortisol responses to injection stress and to LDCST.

\section{MATERIAL AND METHOD}

\section{Patient Selection}

Twenty-five patients ( $22 \mathrm{~F}, 3 \mathrm{M}$ ) between the ages of 21 years and 60 years who were admitted to the Endocrinology and Metabolic Diseases Outpatient Clinic with an indication of cosyntropin stimulation test found at the clinical/laboratory evaluation were included in the study. Preexisting hypophyseal disease [operated hypophysis adenoma $(n=4)$, prolactinoma $(n=3)$, acromegaly $(n=2)$, empty sella $(n=3)$, partial hormone deficiency $(n=1)$, microadenoma $(n=1)$ ] were seen in 14 of the patients, and 12 had cortisol levels of $<10 \mu \mathrm{g} / \mathrm{dL}$ and accompanying symptoms. Pregnancy, breastfeeding, serious comorbidities and patients still receiving steroid therapy were not included in the study.

\section{Design}

Our study was planned as a cross-sectional, placebo-controlled, single-blind pilot study.

Tests were conducted in two consecutive days AT around 8:00-9:00 am, following 8-12 hours of fasting. On the first day, a cannula was placed in the forearm of the patient to assess injection stress and from the other forearm, $1 \mathrm{~mL} 0.9 \%$ saline was injected via direct intravenous injection. This was follwed by 2 $\mathrm{mL}$ of $0.9 \%$ saline injection. On the second day, a cannula was placed in the forearm of the patient in a similar manner for LDCST and $1 \mathrm{~mL}$ of $1 \mu \mathrm{g} / \mathrm{mL}$ 
cosyntropin solution was given via direct intravenous injection from the other forearm. This was followed by injection of $2 \mathrm{~mL} \% 0.9$ saline. Blood samples were taken from the other forearm for measurement of plasma cortisol at $30^{\text {th }}$ and $60^{\text {th }}$ minutes, immediately before the application of saline and cosyntropin. During the test, the patients were kept in sitting position.

Preparation of $1 \mu \mathrm{g}$ cosyntropin solution: $1 \mu \mathrm{g} / \mathrm{mL}$ cosyntropin solution was obtained by adding 1 ampoule of Synacthen $250 \mu \mathrm{g} / 1 \mathrm{~mL}$ (Sigma-Tau Industrie Farmaceutiche Riunite S.p.A. Viale Shakespeare, 4700144 Rom, Italien) into $249 \mathrm{~mL}$ $0.9 \%$ sterile saline. The present solution was kept in the refrigerator for 2 months at $4{ }^{\circ} \mathrm{C}-8{ }^{\circ} \mathrm{C}$.

Cortisol levels were measured by immunoassay method using the Access Cortisol kit (Beckman Coulter, Inc. USA) with Beckman Coulter UniCel DxI 800 automatic analyzer, ACTH levels were measured by the immunometric chemiluminescence method with the Immulite $2000 \mathrm{XPI}$ (Siemens) automatic analyzer using the ACTH kit (ACT Immulite 2000 systems, Siemens, UK). Adequate peak cortisol levels at $30^{\text {th }}$ and $60^{\text {th }}$ minutes after LDCST were taken as $\geq 18 \mu \mathrm{g} / \mathrm{dL}$.

Approval was obtained from the local ethics committee before the study. Information was provided to all the participants about the procedure and written informed consent was obtained from those who agreed to participate.

\section{Statistical Analysis}

Statistical analyzes were performed using the IBM SPSS (Statistical Package for the Social Science, version 17.0) program. Data were given as mean \pm standard deviation (SD) for normal distribution, and as median value and values between $25 \%$ and $75 \%$ quartiles for non-normal distribution. The normal distribution of the data was assessed by the Kolmogorov-Smirnov test. The paired-t test was used to compare data. A p value of $<0.05$ was accepted as significant for all statistical analyzes.

\section{RESULTS}

Twenty-five (22 F, $3 \mathrm{M}$ ) patients with suspected secondary adrenal insufficiency were included in the study. The mean age of the patients was $44.74 \pm 9.70$ years. The pre-test median ACTH and mean plasma cortisol levels were $22.10 \mathrm{pg} / \mathrm{mL}$ (14.00-29.30) and $6.71 \pm 2.00 \mu \mathrm{g} / \mathrm{dL}$, respectively (Table- 1 ). The baseline plasma cortisol values measured at 0th minute in the placebo test for comparison of $1 \mu \mathrm{g}$ cosyntropin stimulation and injection stress were similar, while there was a statistically significant difference was

Table-1: Demographic and biochemical characteristics of patients

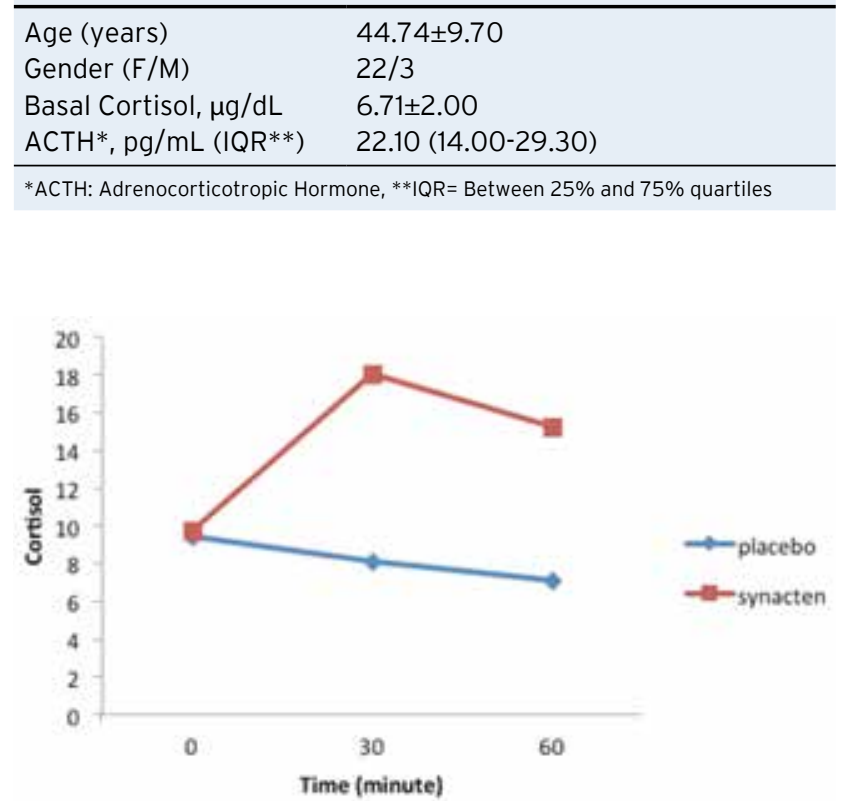

Figure-1: Cortisol responses according to time in placebo and $1 \mu \mathrm{g}$ of cosyntropin test

Table-2: Comparison of $1 \mu \mathrm{g}$ cosyntropin stimulation test results with placebo

\begin{tabular}{lccl}
\hline & LDCST $^{*}$ & Placebo & p value \\
\hline 0.min Cortisol $(\mu \mathrm{g} / \mathrm{dL})$ & $9.69 \pm 3.95$ & $9.29 \pm 3.56$ & 0.459 \\
30.min Cortisol $(\mu \mathrm{g} / \mathrm{dL})$ & $18.38 \pm 3.80$ & $6.88 \pm 2.19$ & $<0.001$ \\
$60 . \mathrm{min}$ Cortisol $(\mu \mathrm{g} / \mathrm{dL})$ & $15.27 \pm 4.06$ & $7.89 \pm 2.37$ & $<0.001$ \\
\hline
\end{tabular}

₹LDCST: Low-Dose Cosyntropin Stimulation Test 
found between the plasma cortisol values measured at $30^{\text {th }}$ and $60^{\text {th }}$ minutes $(p<0.001)$ (Table-2 and Figure-1).

Adequate cortisol response was obtained in $68 \%$ $(n=17)$ of patients at $30^{\text {th }}$ minute and in $28 \%(n=7)$ at $60^{\text {th }}$ minutes following LDCST when we took the cut off value for peak cortisol level as $\geq 18 \mu \mathrm{g} / \mathrm{dL}$. In eight patients, adequate cortisol response could not be obtained after LDCST. No cortisol response exceeding this threshold was found in any of the patients at the $30^{\text {th }}$ and $60^{\text {th }}$ minutes after the placebo test in which the injection stress was assessed.

\section{DISCUSSION}

Adrenal insufficiency, of which the early diagnosis is crucial, is a disease that may persist with nonspecific symptoms, as it may also cause serious clinical symptoms (hypotension, shock, electrolyte disturbances, etc.) in stress situations. Cosyntropin stimulation tests are commonly used to diagnose AI. However, the appropriate cosyntropin dose to assess hypothalamic-pituitary-adrenal (HPA) axis in the case of suspected adrenal insufficiency is still controversial.

CST measures the direct adrenal reserve and is the most commonly used test to identify primary or extended secondary adrenal insufficiency (9). However, because the pharmacological dose of ACTH is used in CST, it is supraphysiological (3). This test leads to ongoing debate on whether it predicts early secondary adrenal insufficiency accurately or not. Although patients sometimes respond normally to CST, they may produce an abnormal response to ITT, which is accepted as the gold standard test for evaluation of the HPA axis (5). Therefore, LDCST is especially recommended for the diagnosis of secondary adrenal insufficiency $(6,10)$. In addition, it also has additional advantages such as the absence of side effects of LDCST, its cost-effectiveness and being easily available for the exclusion of adrenal insufficiency in outpatient clinics (11).

Although there is no consensus on which diagnostic test may be optimal, several meta- analyzes have acknowledged and encouraged LDCST to show higher sensitivity, especially in moderate to mild adrenal insufficiency (12-14). However, the absence of commercially available 1 $\mu \mathrm{g}$ cosyntropin preparations results in different $\mathrm{ACTH}$ formulations to be used in different studies and concerns that arise from different dilution techniques.

The cortisol in humans is released at a circadian rhythm, with a maximum level at 7:00-9:00 in the morning and a lowest level at midnight. However, cortisol is a stress hormone which is stimulated by serious cardiovascular, infectious, and by a degree of psychological stress (4). Intravenous injection also causes a physiological stress. In fact, this stress may be intense that at some point, it may cause syncope. $1 \mu \mathrm{g}$ of cosyntropin is the physiological stress dose. Some studies investigating the effect of LDCST administration technique have shown that the drug preparation technique, storage conditions, the length of the plastic tube used, and test administration time may have an impact on cortisol responses (15-17). However, in our literature review we did not find a study that evaluated the cortisol response in injection stress and compared LDCST with such physiological stress.

The physiological injection stress that occurred during the intravenous injection in our study did not lead to a significant increase in cortisol responses during the test. On the other hand, LDCST performed with $1 \mu \mathrm{g} / \mathrm{mL}$ cosyntropin solution at appropriate preparation and storage conditions showed a significant cortisol response at $30^{\text {th }}$ and $60^{\text {th }}$ minutes compared to the placebo test. In addition, we found that the $30^{\text {th }}$ minute peak cortisol response was higher in our study, which was consistent with the literature $(14,18,19)$. Saiegh et al. (16) showed that $60^{\text {th }}$ minute serum free cortisol alue was higher than the $30^{\text {th }}$ minute value in $10-35 \%$ of cases in healthy volunteers. In our study, however, no cortisol response was obtained at $60^{\text {th }}$ minute in any patient in whom we could not receive a peak cortisol response at $30^{\text {th }}$ minute.

This placebo-controlled study was conducted in patients with suspected adrenal insufficiency. It might 
have been more appropriate to perform this study among healthy volunteers. However, the results obtained show that the $1 \mu$ g cosyntropin stimulation test is highly effective in assessing the diagnosis of secondary adrenal insufficiency.

\section{REFERENCES}

1. Laureti S, Falorni A. Reliability of the ACTH low dose test in the evaluation of adrenal insufficiency. J Postgrad Med 2002; 48: 251-2.

2. Deutschbein T, Unger N, Mann K, Petersenn S. Diagnosis of secondary adrenal insufficiency: unstimulated early morning cortisol in saliva and serum in comparison with the insulin tolerance test. Horm Metab Res 2009; 41: 834-9. [CrossRef]

3. Dickstein G. Hypothalamo-pituitary-adrenal axis testing: nothing is sacred and caution in interpretation is needed. Clin Endocrinol (Oxf). 2001; 54: 15-6. [CrossRef]

4. Grossman A. Assessment of the HPA Axis: Another New Test? Endocrine 2015; 50: 268-9. [CrossRef]

5. Soule SG, Fahie-Wilson M, Tomlinson S. Failure of the short ACTH test to unequivocally diagnose long-standing symptomatic secondary hypoadrenalism. Clin Endocrinol (Oxf) 1996; 44: 137 40. [CrossRef]

6. Gandhi PG, Shah NS, Khandelwal AG, Chauhan P, Menon PS. Evaluation of low dose ACTH stimulation test in suspected secondary adrenocortical insufficiency. J Postgrad Med 2002; 48: 280-2.

7. Patel L, Clayton PE. Clinical usefulness of the low dose ACTH test. J Endocrinol Invest 1999; 22: 401-4. [CrossRef]

8. Streeten DH. Shortcomings in the low-dose (1 microg) ACTH test for the diagnosis of ACTH deficiency states. J Clin Endocrinol Metab 1999; 84: 835-7.

9. Oelkers W, Diederich S, Bähr V. Diagnosis and therapy surveillance in Addison's disease: rapid adrenocorticotropin (ACTH) test and measurement of plasma ACTH, renin activity, and aldosterone. J Clin Endocrinol Metab 1992; 75: 259-64.

10. Dickstein G, Spigel D, Arad E, Schechner C. One microgram is the lowest ACTH dose to cause maximal cortisol response. There is no diurnal variation of cortisol response to submaximal ACTH stimulation. Eur J Endocrinol 1997; 137: 172-5. [CrossRef]
As a result; LDCST performed with $1 \mu \mathrm{g} / \mathrm{mL}$ cosyntropin solution is highly effective in assessing the diagnosis of sec-ondary adrenal insufficiency and physiological injection stress occuring during the test does not cause significant cortisol increase.

11. Ambrosi B, Barbetta L. The role of the low dose ACTH test in the evaluation of central hypoadrenalism. J Endocrinol Invest 1999; 22: 492-5. [CrossRef]

12. Abdu TA, Elhadd TA, Neary R, Clayton RN. Comparison of the low dose short synacthen test (1 microg), the conventional dose short synacthen test (250 microg), and the insulin tolerance test for assessment of the hypothalamo-pituitary-adrenal axis in patients with pituitary disease. J Clin Endocrinol Metab 1999; 84: 838-43.

13. Beishuizen A, van Lijf JH, Lekkerkerker JF, Vermes I. The low dose $(1$ microg) ACTH stimulation test for assessment of the hypothalamo-pituitary-adrenal axis. Neth J Med 2000; 56: 91-9. [CrossRef]

14. Kazlauskaite R, Evans AT, Villabona CV, Abdu TA, Ambrosi B, Atkinson $A B$, et al. Corticotropin tests for hypothalamic-pituitaryadrenal insufficiency: a metaanalysis. J Clin Endocrinol Metab 2008; 93: 4245-53. [CrossRef]

15. Wade M, Baid S, Calis K, Raff H, Sinaii N, Nieman L. Technical details influence the diagnostic accuracy of the 1 microg ACTH stimulation test. Eur J Endocrinol 2010; 162: 109-13. [CrossRef]

16. Saiegh L, Abu-Ahmad A, Sheikh-Ahmad M, Reut M, Chen-Konak $L$, Jiries $N$, et al. Performance of low-dose cosyntropin stimulation test handled via plastic tube. Endocrine 2017; 57: 46-50. [CrossRef]

17. Murphy H, Livesey J, Espiner EA, Donald RA. The low dose ACTH test--a further word of caution. J Clin Endocrinol Metab 1998; 83: 712-3.

18. Cartaya J, Misra M. The low-dose ACTH stimulation test: is 30 minutes long enough? Endocr Pract 2015; 21: 508-13. [CrossRef]

19. Tordjman K, Jaffe A, Grazas N, Apter C, Stern N. The role of the low dose (1 microg) Adrenocorticotropin test in the evaluation of patients with pituitary disease. J Clin Endocrinol Metab 1995; 80: 1301-5. 